\title{
SYNTHESIS, CHARACTERIZATION AND ANTI-MICROBIAL ACTIVITY OF NEW STEROIDAL CHOLEST-5-EN-7-ONE DERIVATIVES FUSED WITH SUBSTITUTED PYRAZOLINE RING
}

\author{
SHAMSUZZAMAN*, MOHD. SHAHEEN KHAN, MAHBOOB ALAM
}

Department of Chemistry, Aligarh Muslim University, Aligarh, 202002, India

(Received: December 31, 2009 - Accepted: August 31, 2009)

\begin{abstract}

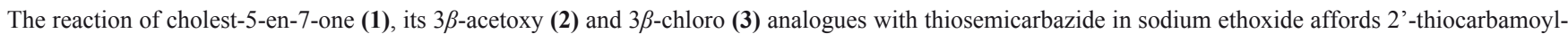
cholest $[5,7$-cd] pyrazoline (4), 2'-thiocarbamoyl-3 $\beta$-acetoxycholest [5,7-cd] pyrazoline (5), and 2'-thiocarbamoyl-3 $\beta$-chloro cholest [5,7-cd] pyrazoline (6), respectively. The structures of the newly synthesized compounds have been established on the basis of physical, analytical and spectral data. Their antibacterial activities were tested in vitro by disk diffusion assay against Gram-positive and Gram-negative bacterial strains of bacteria.
\end{abstract}

Keywords: thiosemicarbazide, pyrazolines, cholest-5-en-7-one, thiocarbamoyl, anti-bacterial activity.

\section{INTRODUCTION}

In recent years, bacterial infections have increased markedly which have caused severe health problems in some subtropical regions of the world Parasitic bacteria such as Bacillus subtilis, S. pyogenes, Staphylococcus aureus, Pseudomonas aeruginosa, Klebsiella pneumoniae and Escherichia coli are responsible for millions of deaths each year. Generally food poisoning, rheumatic, salmonellosis and diarrhea are caused by these bacteria ${ }^{1}$. These different parasitic bacteria have important effect on the human's mucosal health. The infection with these micro organisms may have significant impact on huge demolition of host tissue and severe diseases. ${ }^{2}$ For this reason the present strategy for the synthesis of new compounds is aimed in the direction of developing new pyrazoline derivatives to inhibit the growth of Gram-positive and Gram-negative bacteria.

Pyrazoline derivatives are important electron rich nitrogen heterocycles which play an important role in the diverse biological activities. These nitrogen heterocycles widely occur in nature in the form of alkaloids, vitamins, pigments and as constituents of plant and animal cells. Substituted pyrazoline derivatives have significant importance due to their wide spread pharmacological properties such as anti-bacterial, antifungal, herbicidal and anti-choligenic. ${ }^{3-9}$

On account of the above pharmaceutical interest and in continuation of our previous work,,$^{10,11}$ we undertook the synthesis of some substituted steroidal pyrazolines (4-6).

\section{EXPERIMENTAL}

All melting points are uncorrected and were taken in the open capillaries. IR spectra were recorded in $\mathrm{KBr}$ pellets on Shimadzu $8201 \mathrm{PC}$ (FTIR). ${ }^{1} \mathrm{H}$ NMR and ${ }^{13} \mathrm{C}$ NMR spectra were obtained in $\mathrm{CDCl}_{3}$ with a Bruker DRX$300 \mathrm{MHz}$ spectrophotometer using tetramethylsilane as an internal standard. Satisfactory elemental analyses were obtained for the compounds.

Preparation of steroidal pyrazolines (General procedure)

A solution of cholest-5-en-7-one (1-3) $(5 \mathrm{mmol})$ and thiosemicarbazide $(6$ $\mathrm{mmol}$ ) in sodium ethoxide [sodium metal $(230 \mathrm{mg}, 10 \mathrm{mmol})$ in $13 \mathrm{~mL}$ absolute ethanol] was refluxed for $6 \mathrm{hrs}$. The progress of reaction was monitored by thin layer chromatography. After completion of reaction, reaction mixture was concentrated under reduced pressure and acidified with $\mathrm{HCl}$. It was cooled and then poured into cold water. The obtained solid, was extracted with ether and ethereal layer was washed with water, $\mathrm{NaHCO}_{3}$ solution (5\%), again with water and dried over anhydrous sodium sulphate. The solvent was evaporated and the product was crystallized from dry methanol to give compound (4-6). The results are given in Table 2 and 3.
Table 1: Minimum inhibition concentration (MIC) of cholest-5-en-7-one derivatives and positive control (chloramphenicol)

\begin{tabular}{lclll}
\hline MIC $(\mu \mathrm{g} / \mathrm{ml})$ & Compounds & & Positive \\
\hline Strains & $\mathbf{4}$ & $\mathbf{5}$ & $\mathbf{6}$ & Control \\
\hline B. subtilis & 64 & 16 & 32 & 32 \\
S. pyogenes & 128 & 64 & 64 & 32 \\
S. aureus & 64 & 64 & 32 & 32 \\
P. aeruginosa & 64 & 32 & 32 & 32 \\
S. typhimurium & 64 & 64 & 32 & 32 \\
E.coli & 138 & 64 & 64 & 32 \\
\hline
\end{tabular}

\section{RESULTS AND DISCUSSION}

The present work deals with the preparation of substituted steroidal pyrazolines (4-6) in high yields by reacting compounds (1-3) with thiosemicarbazide in sodium ethoxide (Scheme 1) followed by cyclization. The products so obtained were found selectively as the sole product and the given method of formation of these pyrazolines is simple straight-forward and high yielding. The structures of the products were confirmed with the help of spectral studies (IR, ${ }^{1} \mathrm{H}$ NMR, ${ }^{13} \mathrm{C}$ NMR and Mass).
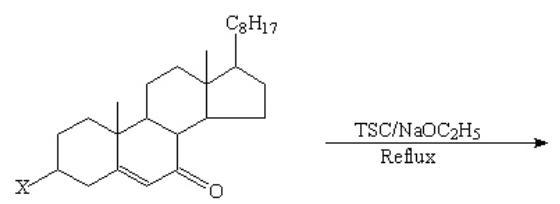

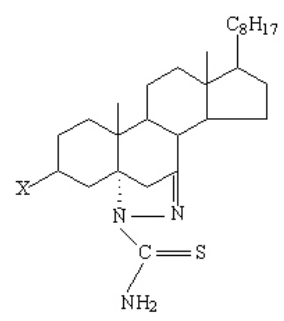

1-3

4-6

$\mathrm{X}$

$\mathrm{X}$

$\mathrm{AcO} \quad(2)$

$\mathrm{Cl} \quad(3)$

(4)

$\mathrm{AcO} \quad(\mathbf{5})$

$\mathrm{Cl} \quad(\mathbf{6})$ 
Table 2: Physical and analytical data of Compounds (4-6)

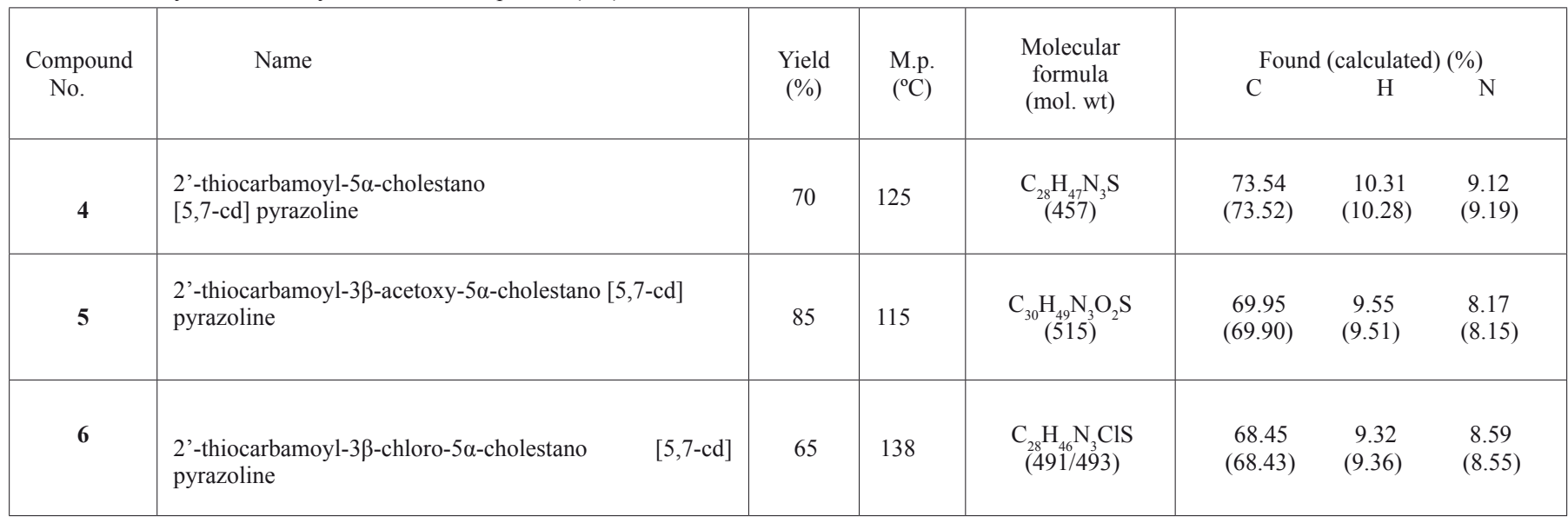

Table 3: Spectral data of Compounds (4-6)

\begin{tabular}{|c|c|c|c|}
\hline Compound & $\operatorname{IR}(\mathrm{KBr})\left(\mathrm{cm}^{-1}\right)$ & ${ }^{1} \mathrm{H} \mathrm{NMR}\left(\mathrm{CDCl}_{3}\right)(\delta, \mathrm{ppm})$ & ${ }^{13} \mathrm{C} \mathrm{NMR}\left(\mathrm{CDCl}_{3}\right)(\delta, \mathrm{ppm})$ \\
\hline 4 & $\begin{array}{lll}3428.4 & \left(\mathrm{NH}_{2}\right), & 1218.5 \\
(\mathrm{C}=\mathrm{S}), & 1168.9 & (\mathrm{C}-\mathrm{N}) \\
1599(\mathrm{C}=\mathrm{N}) & \end{array}$ & $\begin{array}{l}8.7\left(\mathrm{~s}, 2 \mathrm{H}, \mathrm{NH}_{2}\right), 1.13\left(\mathrm{~s}, 3 \mathrm{H}, \mathrm{C}_{10}-\mathrm{CH}_{3}\right) \\
0.70\left(\mathrm{~s}, 3 \mathrm{H}, \mathrm{C}_{13}-\mathrm{CH}_{3}\right) 0.95\left(\mathrm{~d}, 3 \mathrm{H}, \mathrm{C}_{20}-\right. \\
\left.\mathrm{CH}_{3}\right), 0.87\left(\mathrm{~d}, 6 \mathrm{H}, \mathrm{C}_{25}-2 \times \mathrm{CH}_{3}\right)\end{array}$ & $\begin{array}{l}\text { C2' (178.48), C3 (25.23), C4(39.57), C5 (63.8), C6 (63.94), C7 } \\
\text { (153.82), C8 (32.83), C9 (51.68), C10 (35.96), C11 (21.54), C12 } \\
\text { (40.60), C13 (42.38), C14 (56.54), C15 (28.08), C16 (28.26), C17 } \\
\text { (56.30), C18 (11.86), C19 (17.33), C25 (28.08), C26 (21.78), C27 } \\
(22.64)\end{array}$ \\
\hline 5 & $\begin{array}{lcc}3450.1 & \left(\mathrm{NH}_{2}\right), & 1212.8 \\
(\mathrm{C}=\mathrm{S}) & 1168.4 & (\mathrm{C}-\mathrm{N}) \\
1632.4 & (\mathrm{C}=\mathrm{N}) & 1735 \\
1299 & \left(\mathrm{CH}_{3} \mathrm{COO}\right) & \end{array}$ & $\begin{array}{l}8.6\left(\mathrm{~s}, 2 \mathrm{H}, \mathrm{NH}_{2}\right), 4.6\left(\mathrm{~m}, 1 \mathrm{H}, \mathrm{C}_{3}-\alpha \mathrm{H},\right. \\
\mathrm{W} 1 / 215 \mathrm{~Hz}, \mathrm{~A} / \mathrm{B} \text { trans }), 2.02(\mathrm{~s}, 3 \mathrm{H}, \\
\left.\mathrm{CH}_{3} \mathrm{COO}\right), 1.17\left(\mathrm{~s}, 3 \mathrm{H}, \mathrm{C}_{10}-\mathrm{CH}_{3}\right), 0.67(\mathrm{~s}, \\
\left.3 \mathrm{H}_{1} \mathrm{C}_{13}-\mathrm{CH}_{3}\right) 0.93\left(\mathrm{~d}, 3 \mathrm{H}_{2} \mathrm{C}_{20}-\mathrm{CH}_{3}\right), 0.85 \\
\left(\mathrm{~d}, 6 \mathrm{H}, \mathrm{C}_{25}-2 \times \mathrm{CH}_{3}\right)\end{array}$ & $\begin{array}{l}\mathrm{CH}_{3} \mathrm{COO}(170.61), \mathrm{C} 2{ }^{\prime}(179.50), \mathrm{C} 3 \text { (71.41), C5 (62.8), C6 (63.65), } \\
\mathrm{C} 7(153.21), \mathrm{C} 8(35.72), \mathrm{C} 9(51.04), \mathrm{C} 10(35.08), \mathrm{C} 11(21.39), \mathrm{C} 2 \\
(39.55), \mathrm{C} 13(42.34), \mathrm{C} 14(55.90), \mathrm{C} 15(27.27), \mathrm{C} 16(28.21), \mathrm{C} 17 \\
(56.21), \mathrm{C} 18(11.83), \mathrm{C} 19(17.10), \mathrm{C} 25(28.07), \mathrm{C} 26(22.63), \mathrm{C} 27 \\
(22.63)\end{array}$ \\
\hline 6 & $\begin{array}{lll}3426.5 & \left(\mathrm{NH}_{2}\right), & 1286.4 \\
(\mathrm{C}=\mathrm{S}), & 1129.4 & (\mathrm{C}-\mathrm{N}) \\
1589 & (\mathrm{C}=\mathrm{N}), 776 & (\mathrm{C}-\mathrm{Cl})\end{array}$ & $\begin{array}{l}8.8\left(\mathrm{~s}, 2 \mathrm{H}, \mathrm{NH}_{2}\right), 3.9\left(\mathrm{~m}, 1 \mathrm{H}, \mathrm{C}_{3}-\alpha \mathrm{H},\right. \\
\mathrm{W} 1 / 217 \mathrm{~Hz}, \mathrm{~A} / \mathrm{B} \text { trans }), 1.10 \mathrm{~s}\left(3 \mathrm{H}, \mathrm{C}_{10}\right. \\
\left.\mathrm{CH}_{3}\right), 0.74\left(\mathrm{~s}, 3 \mathrm{H}, \mathrm{C}_{13}-\mathrm{CH}_{3}\right), 0.95(\mathrm{~d}, 3 \mathrm{H} \\
\left.\mathrm{C}_{20}-\mathrm{CH}_{3}\right), 0.87\left(\mathrm{~d}, 6 \mathrm{H}, \mathrm{C}_{25}-2 \times \mathrm{CH}_{3}\right)\end{array}$ & $\begin{array}{l}\text { C2' (176.61), C3 (59.6), C5 (63.08), C6 (63.70), C7 (152.81), C8 } \\
\text { (32.58), C9 (51.51), C10 (35.79), C11 (21.98), C12 (42.38), C13 } \\
(42.30), \text { C14 (56.25), C15 (23.89), C16 (28.21), C17 (56.21), C18 } \\
(11.82), \text { C19 (16.98), C25 (29.81), C26 (22.65), C27 (21.98) }\end{array}$ \\
\hline
\end{tabular}

The elemental analysis of the compound 4 corresponds to the molecular formulae $\mathrm{C}_{28} \mathrm{H}_{47} \mathrm{~N}_{3} \mathrm{~S}$. The IR data were very informative and provided evidence for the formation of the expected structure. The compound showed intense band in the region of $1281.5 \mathrm{~cm}^{-1}$ due to $(\mathrm{C}=\mathrm{S})$ stretching of the thiocarbamoyl group and another band at $3428.4 \mathrm{~cm}^{-1}$ which could be assigned to $\mathrm{NH}$ group. In addition, other important absorption bands at $1168.9 \mathrm{~cm}^{-1}$ and $1599.5 \mathrm{~cm}^{-1}$ were attributed to $(\mathrm{C}-\mathrm{N})$ and $(\mathrm{C}=\mathrm{N})$ respectively, which also confirm the formation of expected pyrazoline moiety ${ }^{10,12}$ in the product molecule. Further, evidence for the formation of structure 4 was well supported by its ${ }^{1} \mathrm{H}$ NMR and ${ }^{13} \mathrm{C}$ NMR. It's ${ }^{1} \mathrm{H}$ NMR spectrum exhibited a two-proton singlet at $\delta 8.7$ for $\mathrm{NH}_{2}$ (exchangeable with $\mathrm{D}_{2} \mathrm{O}$ ), other important peaks were observed at $\delta 1.13,0.95$, 0.87 , and 0.70 indicating the presence of angular and side chain methyl protons of steroidal skeleton. ${ }^{13} \mathrm{C}$ NMR spectrum of the compound also supported the proposed structure. Thiocarbamoyl carbon (C2') exhibited a signal at $\delta 178.48$. On the account of the above descriptive discussion, the compound can be suitably characterized as 2'-thiocarbamoyl-5 $\alpha$-cholestano [5,7-cd] pyrazoline 4. Similarly, the structures of compound 5 and $\mathbf{6}$ have been established on the basis of their elemental analysis and spectral data. The stereochemical assignation has been performed on the basis of half band width $\left(\mathrm{W}_{1 / 2}\right)$ values of $\mathrm{C}_{3}$-axial proton in the ${ }^{1} \mathrm{H}$ NMR spectra of compounds $\mathbf{5}$ and $\mathbf{6}$ which clearly suggested that $\mathrm{A} / \mathrm{B}$ ring junction is trans. ${ }^{13}$

The synthesized compounds were evaluated for their in vitro antimicrobial activity against several bacterial strains by the disk diffusion method ${ }^{14}$ and subsequently the minimum inhibitory concentration (MIC) of all the compounds was determined. Compounds (4-6) have cholestan, $3 \beta$-acetoxy, and $3 \beta$-chloro groups, respectively. The MIC is the lowest concentration of the test compound, which can restrain the observable growth after $18 \mathrm{~h}$ incubation at $37^{\circ} \mathrm{C}$. The MIC was determined visually after incubation for $18 \mathrm{~h}$, at $37^{\circ} \mathrm{C}$. The in vitro study results demonstrated that the compound $\mathbf{4}$ was found to be the most active among the three compounds.

\section{MICROBIOLOGY}

Tested microorganism strains Bacillus subtilis, S. pyogenes, Staphylococcus aureus, Pseudomonas aeruginosa, Klebsiella pneumoniae and Escherichia coli were inoculated in BHI medium and incubated for $18 \mathrm{hrs}$ at $37^{\circ} \mathrm{C}$, and after that the bacterial cells were suspended in autoclaved saline solution according to the McFarland protocol to create a suspension of about 
$10^{5} \mathrm{CFU} \mathrm{mL}$. Then $10 \mathrm{~mL}$ of sterile antibiotic agar was mixed with $10 \mu \mathrm{L}$ saline suspension of about $10^{5} \mathrm{CFU} \mathrm{mL}^{-1}$ at $40^{\circ} \mathrm{C}$ and then poured onto an agar plate $(90 \mathrm{~mm}$ diameter) in a laminar flow cabinet. Five paper disks $(6.0 \mathrm{~mm}$ diameter) were set onto nutrient agar plate. $1 \mathrm{mg}$ of every trial compound was dissolved in $100 \mu \mathrm{l}$ DMSO to prepare stock solution and from stock solution diverse concentrations $10,20,25,50$, and $100 \mu \mathrm{g} / \mu \mathrm{l}$ of every trial compound were prepared. The susceptibility of the Gram-positive and Gram-negative bacterial strains to the trial compounds was assessed by the formation of zone of inhibition after $18 \mathrm{~h}$ of incubation at $37{ }^{\circ} \mathrm{C}$. Compounds were dissolved in dimethyl sulfoxide (DMSO) then serial dilutions of the test compounds, were prepared to final concentrations of 512, 256, 128, 64, 32, 16, 8, 4, 2 and $1 \mathrm{mg}$ / $\mathrm{mL}$ to each tube was added $100 \mathrm{~mL}$ of a $24 \mathrm{~h}$ old inoculums. Chloramphenicol was used as a positive control. The observed data on the antibacterial activity of the compounds and the standard drug was given in Table 1.

\section{CONCLUSION}

In conclusion, we have achieved a simple single-step procedure for the synthesis of three new steroidal cholest-5-en-7-one derivatives fused with substituted pyrazoline ring in excellent yields. The compounds were also evaluated for their antibacterial activities

\section{ACKNOWLEDGMENT}

The authors thank to the Chairman, Department of Chemistry, A.M.U., Aligarh, for providing necessary research facilities and also to the University Grants Commission, New Delhi for the financial support in the form of Major Research Project [UGC-Scheme-F.No. 33-263/2007 (SR)]. Authors are also thankful to the Department of Biochemistry, A.M.U., Aligarh, for providing facilities for biological studies.

\section{REFERENCES}

1. S. A. Khan, P. Kumar, R. Joshi, P. F. Iqbal, K. Saleem, Eur. J. Med. Chem. 43, 2009 (2208)

2. S. A. Puertoa, G. J. Fernandeza, L. D. J. Castillob, M. Jose, S. Pinoa, P. G. Anguloa, Diagn. Microbio. Infect. Dis. 54, 135 (2006).

3. N. Gokhan, A. Yesilada, G. Ucar, K. Erol, A.A. Bilgin, Arch. Pharm. 336, 362(2003).

4. M. S. Shingar, B. H. Siddiqui, Arzeimittel-forsch. 338, 96 (2006).

5. F. Chimenti, B. Bizzarri, F. Manna, A. Bolasco, D. Secci, Chimenti, P. Granese, A. Scaltrio, Biorg. Med. Chem. Lett. 15, 603 (2005).

6. R. Soliman, N. S. Habib, F. A. Ashour, M. el-Taiebi, Bollettino Chomico Farmaceutico 140, 140 ((2001).

7. E. Palaska, M. Aytemir, T.I. Uzbay, D. Erol, Eur. J. Med. Chem. 36, 539 (2001).

8. S. Guinzkucukguzel, S. Rollas, Farmaco II 35, 761 (2002).

9. A. A. Bekhit, H. M. A. Ashour, A. A. Guemei, Arch. Pharm. 338, 167 (2005).

10. Shamsuzzaman, N. Siddiqui, Indian J. Chem. 42(B), 3139 (2003).

11. Shamsuzzaman, M. Aslam, Anwar Salim, J. Chem. Research (S) (U.K.) 12, 824 (1998)

12. A. Ozedmir, G. Tulan-Zitouni, Z. A. Kaplancikh, G. Revial, K. Guven, Eur. J. Med. Chem. 42, 403 (2007).

13. N. S. Bhacca, D. H. Williams, Application of NMR spectroscopy in organic chemistry, Holden Day, San Francisco, 1964

14. S. A. Khan, K. Saleem, Z. Khan, Eur. J. Med. Chem., 42, 103 (2007). 